\title{
Bridging equity? Washington, D.C.'s new elevated park as a test case for just planning
}

Nufar Avni*

*School of Urban Planning, McGill University, 400 MacDonald Harrington Building, 815

Sherbrooke St. West, Montreal, Quebec, Canada H3A 2K6

nufar.avni@mail.mcgill.ca

$1-514-622-0526$

\begin{abstract}
In the last decade, justice has been revived as a primary criterion for the analysis and evaluation of planning policies. This paper continues the conversation about justice and planning by examining a proposed redevelopment project in Washington, D.C. that sets equitable development as its goal—asking to what extent this model keeps true to its promise. The proposed 11th Street Bridge Park would be a topnotch elevated park, physically and symbolically connecting D.C's wealthy west with the disadvantaged east. The project is managed by a nonprofit organization and seemingly stands out in its progressive social vision: An Equitable Development Plan has been developed in collaboration with various stakeholders, in an attempt to secure the future of the local residents in light of the anticipated gentrification of the neighborhood. However, preliminary findings show that despite explicit commitment to equity, through discourse and action, the planning of the park also resurfaces racial and class tensions that cannot be easily resolved. The analysis of procedural and substantive aspects of justice in this case suggests that issues of recognition, power and representation are instrumental to fully understand urban (in)justices.
\end{abstract}

Key words: $11^{\text {th }}$ Street Bridge Park, Washington, D.C., justice, equity planning, redevelopment 


\section{Introduction}

In the last decade, the field of urban planning has witnessed a proliferation of scholarship on urban (in)justice. While the philosophical notion of justice dates back to antiquity (Connolly \& Steil, 2009), contemporary planning scholars have re-instigated the conversation about how justice can be translated into space, geography and spatial policies (Campbell, 2006; Carmon \& Fainstein, 2013; Lake, 2017; Marcuse et al., 2009; Song, 2015; Yiftachel \& Mandelbaum, 2017). In particular, Suzanne Fainstein's (2010) Just City framework has served as an influential calland model — to analyze justice at the urban scale, contributing both a theoretical foundation and criteria for the evaluation of urban policies. This paper follows Fainstein's engagement with justice as a normative and analytic goal for planning theory and practice, and elaborates on it, by examining a redevelopment project that explicitly promotes equitable development as part of its agenda.

The $11^{\text {th }}$ Street Bridge Park (or Bridge Park) in Washington, D.C. is a proposed elevated park intended to be constructed on the Anacostia River, and also the name of the nonprofit that promotes this initiative in partnership with the District. Often compared to New York's High Line or Atlanta's BeltLine, D.C.'s first elevated park will feature high-quality outdoor recreational spaces and offer improved access to the river. At the same time, the location of Bridge Park between D.C.'s wealthiest and poorest wards—west and east of the river, respectively — means that it would physically and symbolically connect disparate communities. This context has inspired efforts to create an exemplary model of equitable and inclusive planning in an area that has long suffered institutional neglect.

This paper examines the Bridge Park, with a focus on the project leaders' attempts to promote socially equitable development, through the execution of an Equitable Development 
Plan (EDP). The EDP (2015) was created in anticipation of the potentially negative impacts of development, such as gentrification and displacement of longtime residents. It outlines strategies to inclusive, participatory and equitable planning process as well as fair outcomes. Although the Park is still in early pre-construction stage, preliminary lessons about the EDP can already be drawn. My analysis points to Bridge Park's potential promise in promoting equitable planning but also to its challenges and significant limitations. Similarly to Fainstein and others (Campbell \& Marshall, 2006; N. Fainstein \& Fainstein, 2013; Lake, 2017), I pay attention to both procedural and substantive aspects of justice and equity in the analysis of the case. I argue that although Bridge Park seemingly includes extensive efforts to engage the community, it is still questionable whether these efforts are inclusive of the community's most vulnerable members. Moreover, skepticism about the 'real' intensions behind the project is still present. The case of the Bridge Park shows that 'top down' attempts of equity planning may not be compatible with grassroots perceptions of equity. Moreover, the partnership between Bridge Park and the District may result in 'NGOization of justice' that would shift the responsibility away from the government into private hands. The Bridge Park case is significant since even though social justice and equity may (arguably) be among the intensions behind various planning interventions, they are rarely explicitly listed as goals in planning documents, let alone operationalized beyond a vision statement. Moreover, since planning literature often documents injustice rather than justice (Campbell, Tait, \& Watkins, 2014; Fincher \& Iveson, 2012; Williams, 2016), it is valuable to examine attempts of bringing justice issues to the planning table.

The paper starts with a brief overview of the literature of social justice in planning. I then present the research methods and introduce the Bridge Park and the context for its formation. 
Next, I discuss Bridge Park through two main themes: the planning process of the park, and its expected outcomes. I pay particular attention to aspects of community engagement, gentrification and displacement. The paper ends with a discussion that ties these elements together with relation to just planning. Ultimately, the Bridge Park project embodies challenges and dilemmas that many policy-makers face in their efforts to endorse equitable planning. It demonstrates that even when attempts are made to promote inclusive and equitable growth in explicit ways, they are not necessarily perceived as genuine or effective by everyone.

\section{Justice and planning}

The ideal of social justice is the bedrock of any democratic society within which citizens can actively participate in a free, tolerant and inclusive political community. (Merrifield \& Swyngedouw, 1996, p. 1)

The discussion on justice and planning — and justice in planning — has been revived in recent years (Fincher \& Iveson, 2012; Heynen, Aiello, Keegan, \& Luke, 2018; Marcuse et al., 2009). In particular, Susan Fainstein's (2010) recent call to consider justice a primary criterion in the evaluation of planning policies has placed it at a center stage in planning theory (Lake, 2017). Cities are places where injustices occur and also in which justice is fought for. And yet, despite the importance of the urban as a sphere where justice is shaped and contested, the meaning of justice in urban life has remained fuzzy (Cardoso \& Breda-Vazquez, 2007; Connolly \& Steil, 2009; Fischer, 2009; Harvey \& Potter, 2009). Since the 1960s, different scholars have placed different emphases on what constitutes as justice. 
Initially thought of as a material, class-based concept, related to unequal production and distribution, and spatial inequalities (Harvey, 1973; Marcuse, 2009; Soja, 2010), theorization of justice has been expanded on to include perspectives of diversity, recognition, and difference (Fraser \& Honneth, 2003; Sandercock, 1998; Young, 1990).

The Just City framework, developed by Susan Fainstein (2010), is one of the most concrete attempts in planning scholarship to develop an urban theory of justice and examine it empirically. Fainstein's point of departure is her critique of urban theories that do not define the criteria for social justice in explicit terms, as well as theories that address justice as a matter of process and not outcome (S. S. Fainstein, 2000, 2005a). To that end, she advocates for a normative approach to planning theory and defines justice as the leading norm for evaluating urban policy. Justice in Fainstein's view is composed of equity, democracy and diversity. Since she recognizes that there may be tensions between the three norms she specifies, she prioritizes equity among them. The Just City thus extends the traditional political-economy approach to include non-material factors, which have been raised by scholars such as Iris Marion Young (1990), Nancy Fraser (1998), Leonie Sandercock (1998), and others, as critical in the analysis of justice. Fainstein is concerned with how justice might be achieved under contemporary conditions, i.e. the political-economic structure of the capitalist urban regime (and in that she differs from the Marxian approach, who sees capitalism as an inherent contradiction to social justice).

The Just City also brings to the forefront issues of representation and participation, which have long been considered important in just planning (Arnstein, 1969; Bratt \& Reardon, 2013; Davidoff, 1965). One of the dominant approaches to procedural aspects of justice in planning 
theory to date has been the communicative (or collaborative) planning model, which draws on Habermas's theory of communicative rationality. This approach highlights the multiplicity of voices and stakeholders that takes part in planning and sees the planner as in charge of bridging between different viewpoints in order to forge consensus (Forester, 1999; Healey, 2003; Innes, 1995). Communicative planning promotes the notion that 'good' or 'just' cities should be planned through a fair and inclusionary process, which brings in a diversity of opinions and representations. Moreover, procedural concerns emphasize that notions of the 'public good' can be contentious, depending on the identity and interests of the various stakeholders (Campbell, 2006). While Fainstein (2005b, p. 125) supports the notion of a democratic and inclusive process, where "no particular group should be privileged in an interchange", she also cautions that open processes can lead to unjust outcomes. Thus, she incorporates elements of fair deliberation and decision-making in the 'democracy' component of the just city, but analytically separates it from 'equity' since, as she emphasizes, democratic processes can be skewed by the interests of the most powerful (see also Huxley \& Yiftachel, 2000).

Fainstein's pragmatic approach has been exposed to varying critiques. For example, Novy and Mayer (2009, p. 116) are skeptical that social justice and a capitalist regime can concur. In their view, Fainstien's pragmatism "unnecessarily constrains the struggle for urban social justice, sweeping alternative visions and alternative possibilities aside”. Others have argued that Fainstein's 'top-down' understanding of justice limits city residents in defining their own concepts of justice while giving too much power to planners, who may exploit their position to advance policies that would marginalize the general public (Uitermark \& Nicholls, 2017). From a different angle, advocates of communicative planning have argued that planning process cannot be easily separated from outcomes (Healey, 2003). Moreover, while Fainstein encourages 
diversity, her treatment of the term has been less developed compared to the other two (democracy and equity) and it is not quite clear how issues of race and ethnicity are to be dealt with by planners (Avni, 2017; Song, 2015).

Importantly, Fainstein's focus on Western liberal democracies not only excludes significant parts of the globe, but to a large extent overlooks oppressive forces such as nationalism and colonialism, which also operate in the places she studies. Indeed, Fainstein explicitly limits her discussion to wealthy countries and she argues for the contextuality of the term justice. However, as Porter and Yiftachel (2017) discuss in a recent special issue about urbanizing settler-colonial studies, global north-western cities also exhibit colonial dimensions. In recent years, scholars of the global south-east have emphasized the 'stubborn realities' (Watson, 2013; Yiftachel, 2006) that shape places, highlighting the contextuality of planning theories and the need to pay attention to the various factors that influence planning policies (Avni \& Yiftachel, 2014; Susan Parnell \& Oldfield, 2014; Roy, 2009). This perspective is relevant to a multi-racial and multi-class city such as Washington, D.C., despite its 'global northwest' affiliation. Applying Feinstein's formulation of the Just City to a redevelopment project in this city (and its stubborn realities) is helpful to further bridge the theoretical discussion about justice with planning practice. At the same time, it reveals the limitations of the Just City, by pointing that 'diversity' may mask deeper issues of race, ethnicity and (mis)recognition (Yiftachel, Goldhaber, \& Nuriel, 2009). These issues will be further discussed throughout the paper.

\section{Methods}


This paper builds on analysis of documents, social media content, 15 interviews, and visits to the study area. The main documents and sources of information include: The Equitable Development Plan (2015) produced by Bridge Park; media coverage of the bridge project between 2014 and 2016 in local and international newspapers and radio shows; posts published by the Bridge Park team on their blog, website and newsletter; and videos of community meetings available online. Specifically, the full contents of the Bridge Park official blog available on their website (2013-2017) were analyzed. I also searched ProQuest and Factiva databases for newspaper articles about the project from 2011-2017, which yielded 130 articles.

To complement this information, fieldwork in D.C. took place in September 2016 and in April 2017. Semi-structured interviews were conducted with eight key stakeholders including Bridge Park staff; partners of the project from other community and environmental nonprofits; and representatives of community organizations based east of the river. Seven additional interviews were conducted with key stakeholders in D.C who were involved in the Anacostia Framework Initiative (AWI) in the last two decades - a District plan to revitalize the Anacostia area_-including planners, representatives of community organizations and environmental NGOs, and academics. These interviews were instrumental in understanding the socio-geographic context for the Bridge Park, which is an indirect outcome of the AWI. Finally, I conducted a participant observation in several community events organized by Bridge Park.

\section{The $11^{\text {th }}$ Street Bridge Park: An overview}

At the time of writing, Bridge Park is in early stages of fundraising and preconstruction work, yet has already attracted widespread attention, nationally and internationally (Kolson Hurley, 2016; Steinhauer, 2014). The park is planned to be built over the Anacostia River, which 
has served for decades as a physical and symbolic boundary separating east and west D.C (Figure 1). Whereas the predominantly white area west of the river is home to D.C's famous landmarks such as the Capitol Hill, the National Mall and the Georgetown waterfront, the predominantly Black neighborhoods east of river in Wards 7 and 8 are amongst the poorest areas of the city, characterized by a history of displacement of residents, public housing projects, and a legacy of environmental contamination (Wennersten, 2008). The deep divide between the two sides of the Anacostia - termed D.C's 'forgotten River'-has driven a comprehensive riverfront redevelopment plan under Mayor Williams's terms (1999-2007): The Anacostia Waterfront Initiative (AWI). As a result of the plan, large riverfront swaths that were previously inaccessible have transformed into areas of intense development in the form of new condominium neighborhoods, parks, office spaces and a ballpark stadium. However, while the plan was supposed to 'reunite' east and west of the District, most of the development occurred west of the river, and so the gaps between Ward 6 on the west and Wards 7 and 8 east of the river have even intensified (Table 1) .

\section{[Table 1]}

The idea for the Bridge Park emerged during the execution of one of the AWI's projects - the replacement of the former $11^{\text {th }}$ Street Bridge highway by a new one. The District's director of planning at the time (2009) envisioned that the piers of the old bridge could be repurposed to create a park, meaningfully connecting the two sides of the river by attracting substantial numbers of locals and visitors to enjoy the park's amenities. From 2011-2013, the former director of planning and Bridge Park's present director, who at the time had no formal role in the project, tested the idea in the nearby communities through hundreds of community 
meetings (Graber, 2014). Later, the project was formalized within the administrative framework of the Ward 8-based nonprofit organization "Building Bridges Across the River (BBAR)", in partnership with the District (Bogle, Diby, Burnstein, Woluchem, \& Dev, 2016).

Since then, work on the future Bridge Park has gained considerable momentum, even though funding efforts are still underway. The District has already committed $\$ 15$ million to the project, and in total over $\$ 25$ million out of the estimated budget of $\$ 50$ million has been raised at the time of writing ${ }^{\mathrm{ii}}$ (Kennicott, 2014; O'Connell, 2017). In 2014, a design competition for the bridge was held and in 2015, Bridge Park published its EDP. Preconstruction instigated in late 2016, and the park is planned to be opened in 2019, assuming funding is obtained. Bridge Park Project's four key goals are: “to improve public health by providing safe places to play and access to fresh food; re-engage residents with the Anacostia River; stitch together neighborhoods that have long been divided by the river, and to serve as an anchor for equitable and inclusive economic growth" (Kent \& Kratz, 2017 n.p).

\section{Inclusive planning or planning to be inclusive? Public engagement and the EDP}

One of the main characteristics of the $11^{\text {th }}$ Street Bridge Park has been the explicit articulation of issues of equity, inclusivity and community engagement in the park's planning, before construction broke ground. Equity aspects have been addressed in different planning stages, including hundreds of formal and informal community meetings prior to the formalization of the project (Interview with the director, 2016); throughout a design competition for the future park, which included an oversight committee with community representatives; and in the drafting of the EDP - a yearlong process that involved the creation of a Task Force consisting of dozens of professionals and community representatives. There, Bridge Park partnered with a leading community development nonprofit (Local Initiatives Support 
Corporation -LISC D.C.) to conceptualize and shepherd the planning process. With the growing realization that the park would induce gentrification east of the river-where about $70 \%$ of the people are renters - the plan's stated goal has been to promote inclusive planning that will protect vulnerable residents from the potentially negative consequences of the park, such as displacement (interview with Bridge Park director; and with LISC's project manager in charge of the EDP, September 2016). The resulting document proposes strategies for job creation, local entrepreneurship and preservation of affordable housing, summarized in Table 2.

\section{[Table 2]}

Bridge Park prides itself for an inclusive planning process that considers not only aspects of public engagement but also implementation issues. Engagement activities range from social media updates including a blog, newsletter, twitter account and a Facebook page, to hosting community events. Interviews with Bridge Park's team and representatives of its partnering organizations repeated the notion that the project is carried out with consensus from local communities and through a participatory approach that values resident's ongoing feedback. As the director of the park mentioned, it is not managed by "a bunch of planners just sitting in a room somewhere" (Interview, September 2016) but in conjunction with the community. While the idea for the bridge was originated by D.C.'s former director of planning, according to Bridge Park's director the initiative really took off once the idea was tested through hundreds of community meetings. In the director's own words:

We went out to the community and asked the community in essence for permission, do the communities want this project?... Because typically planning happens to this 
community and not really with this community and I think if there is any community engagement it's at the tail end of that process: "hey, we have a great project, do you want this?" And that's not completely fair, so I think going and in essence asking for permission is critically important. (Interview, September 2016)

According to proponents of the project, the community engagement model that Bridge Park has adopted goes beyond typical participatory processes, where the public is generally informed and heard by planners and policy makers, but not necessarily engaged in meaningful ways (Arnstein, 1969). According to them, efforts are made to make the community an active player in the process of building the park. A senior employee at an environmental NGO that collaborates with Bridge Park shared his impression of the engagement process:

When [the director] first came to me I thought he was crazy, and then it took me a year and then all of a sudden I realized he was a genius and I've been a huge fan ever since. ... I think that [he] has done a masterful job at doing his Equitable Development Plan, I think it's fabulous. . . [The director] has spent so much time in the community talking with them and working with them and understanding what they felt was important, and now he is implementing that, he is making that happen.

However, interviews with representatives who are not official partners of Bridge Park revealed significant cracks in the inclusiveness narrative of the park. A community organizer at a grassroots organization based east of the river argued that the organization, in addition to other 
grassroots organizations based in Ward 8, were not included in the public engagement process because Bridge Park staff knows that their opinions are not in favor of the project (Interview, April 2017). According to the community organizer, the park is targeted at middle-class residents of the Anacostia, whereas the poor population is excluded from the process and is not likely to benefit from the park. To him, the fact that the project is led by a white, Ward 6 resident (who is a relatively newcomer to D.C.), and not by a Black longtime resident of the Anacostia, is indicative of the racial inequalities that still dominate DC.

Another interview with a community organizer from a nonprofit east of the river disclosed similar views. The interviewee said that while Bridge Park claims to enjoy wide support by the community, in fact, many people east of the river are not even aware of the existence of the project. The interviewee said that promoters of Bridge Park tend to overlook the socio-economic differences between the diverse communities east of the river, not fully realizing that the support of middle-class residents east of the river does not entail that the project targets the very poor, in other words, those who might be more deeply affected by the outcomes of the park. He cautioned that just because events organized by Bridge Park are well-attended does not in itself prove the popularity of the project, since attendees may come from different parts of the District.

Limitations in the community engagement process were also revealed in a conversation with a researcher and former resident of Ward 6 who studied the project's engagement process. As a Bridge Park volunteer, a resident of the impact area and a researcher, she was surprised to discover that many residents of the impact area, especially east of the river, were not aware of the project. She noted the Bridge Park's community engagement process relies heavily on social media and email. However, the illiteracy rate east of the river is quite high and many residents do 
not have a high-speed internet connection. Moreover, the residents who struggle to make a living or do not have jobs, are not prioritizing participation in this project. The researcher explained that Bridge Park staff initially focused their outreach efforts through civic associations in Ward 8, which tend to represent the more educated and already-involved residents rather than the area's marginalized communities. In order to include other audiences, she said, Bridge Park would need to change their outreach strategies and implement inclusive engagement strategies that are intentional about meeting the community where they are. Finally, a civic rights attorney who is also a resident of Anacostia reinforced the notion that many are not aware of the project during a panel broadcasted at a local radio show:

I want to push back a little bit on this notion that Bridge Park is necessarily something that the community wants, even though [the director] may have had 200 meetings. When entities come together and decide that there is going to be a project and they call members of the community to join in, that process is tainted by segments of the community that [are] pro-development, they have interest in the value of their homes, but the average working person in that area is not thinking about Bridge Park. Most people don’t even really know what the project is. (The Kojo Nnamdi show, October 13, 2017, author's emphasis)

These interviews have demonstrated that while Bridge Park enjoys support by many stakeholders, including many Ward 8 residents, a significant number of residents are unaware of it. This means that Bridge Park has neglected to include substantial publics in its work process to date. This finding deeply problematizes the argument made by Bridge Park leaders' about getting 
consent from the community in the first place. Moreover, among the informed residents, some resist the park. Not surprisingly, many of the opposing voices belong to residents who have been experiencing marginalization, including, for example, residents of a former public housing project at Barry Farm neighborhood, which is designated for redevelopment despite their fierce objection to the plan. As another interviewee, a community activist and a resident of Ward 7, pointed out, dissent over the park comes especially from these affected communities due to the historical distrust of the government. Indeed, some skeptical residents have changed their minds about the park over time, now embracing the project. According to their accounts, they have been persuaded by Bridge Park's continuous commitment to its vision and by being personally involved with different sections of the EDP, some in leadership roles. However, this process does not apply to everyone.

Finally, while the EDP represents an effort to promote inclusive development, it is premised on a controversial assumption to begin with - that the park is a positive advancement. As the Director of Bridge Park and the manager at LISC who co-led the EDP said, essentially the work process was based on the premise that the bridge would be built. During meetings with community representatives, members were asked to "assume the park is going to get built" in their comments and suggestions (Interview with the project manager at LISC, September 2016). While this is a reasonable strategy to advance public engagement, it also begs the question if participants could really influence the reality of building the park.

\section{Who Is this for? Considering the outcomes of the $11^{\text {th }}$ Street Bridge Park}

With the stark differences between east and west of the river in terms of land values, land ownership, employment and poverty (Table 1), a topnotch park bridging these juxtaposed 
areas is assumed to have direct outcomes on the real-estate market. Similar projects, such as New York's High Line and Atlanta's BeltLine, have shown that in addition to the advantages associated with high-quality public spaces, these parks typically generate a sharp rise in land values (Curran \& Hamilton, 2012; Larson, 2018). In the Bridge Park case, these changes are likely to affect Wards 7 and 8 more than they would affect the already affluent Ward 6 . While the scale of the Park might not seem significant compared to the extensive neighborhoods around it, examples from around the world suggest that similar-size projects, or even smaller environmental improvements, such as tree plantings, are assumed to have substantial impacts on their surroundings (Anderson \& Cordell, 1988; Heckert \& Mennis, 2012; Pearsall, 2018).

Bearing in mind this context, the Bridge Park project brings forward interesting questions about the value of redevelopment projects for the community - questions which go beyond the inclusiveness of the planning process to address planning outcomes. On the one hand, proponents of the park argue that it will offer amenities that are currently lacking in Ward 8 . The park also creates opportunities for social interaction between D.C's east and west, as well as improved access to the river for all. On the other hand, such large-scale investment certainly has the potential to increase land values in Ward 8, which could speed up gentrification and even cause displacement of residents, due to the large percentage of renters in the area. Changes in Ward 8's housing market are already evident: home prices in Historic Anacostia neighborhood soared in 2015 as "developers and middleclass homebuyers have 'discovered' east of the river" (Kolson Hurley, 2016, n.p.). While the neighborhood is still affordable relative to wealthier ones in D.C, it is becoming increasingly unaffordable to its low-income residents. The park is not the only cause for the increasing real-estate prices, yet even its advocates recognize its impact on the area. 
To a large extent, the critical issue of planning outcomes (N. Fainstein \& Fainstein, 2013) has always been a part of the park's planning. While the project is still ongoing and there is no guarantee that the bridge will eventually get built, Bridge Park has already started implementing some recommendations from the EDP. In the area of housing, Bridge Park partnered with an affordable housing developer, Manna, to create a Home Buyers Club in Ward 8, a project designed to assist low-income residents in purchasing a home through financial assistance and planning. They also work on locating units that can be converted into affordable housing units east of the river. Moreover, lately, Bridge Park has started to promote a Community Land Trust, an idea that came up in community meetings (Interview with the EDP manager, 2017). Recently, Bridge Park successfully secured preliminary funding for the trust, and fundraising efforts continue (Hui, 2017; O'Connell, 2017).

Other areas of intervention include urban agriculture plots, in collaboration with the University of the District of Columbia's College of Agriculture, churches and nonprofits, and arts and culture projects, including collaborating with students in local schools to develop art installations for the future park. Bridge Park also co-organizes festivals and activities such as the annual Anacostia River Festival, film-screenings, cultural events and workshops. In 2016, Bridge Park announced Elevating Equity, a \$50 million-dollar initiative led by LISC D.C, aimed to support implementation of the EDP in the 1-mile radius of the bridge. Finally, Bridge Park recently hired an Equitable Development Manager, whose responsibility is to ensure the implementation of the EDP.

The EDP and the various community events and projects organized by Bridge Park convey a sense of good intensions and suggest that the implications of the project have been taken into consideration well in advance. Accordingly, Bridge Park has enjoyed a very 
supportive media coverage to date; of the over 100 newspaper articles that were reviewed in this research, only a small fraction expressed critique of the project. At the same time, not everyone shares the opinion that the project is desired by the community or that the negative impacts of the park can be mitigated. It seems that there is more than one way to interpret the planning outcomes of the park. If the bridge is going to get built and the issue at stake is guaranteeing that the community would benefit as much as possible from the proposed park, then the EDP provides a implementable strategies to combat at least some of the potentially negative outcomes. If, however, one questions the very idea of building the park, then it becomes debatable whether the EDP is truly equitable in its essence, or, rather, a compromise at best. An interview with a community activist who works at an environmental educational organization and witnessed the process from the start demonstrates this dilemma:

So I was there at the beginning. . . . [The director of planning] came into a meeting, there must have been 80 of us in the room, and she's like, "I want to raise 40 million dollars to build the $11^{\text {th }}$ street Bridge as a recreational park". And we all looked at her like she was crazy. Do you know what we could do with 40 million dollars in a poor neighborhood? We could improve our streets, there is a whole bunch of stuff that we could do (Interview, September 2016).

While this interviewee is nowadays an advocate of the bridge and speaks of voluminous support for the project, the park has caused, and still causes, controversy precisely due to this point. The idea of investing over $\$ 40$ million in a park considering the area's disinvestment and poverty is not accepted by everyone as equitable nor just. For example, the grassroots 
organizations' representatives who were mentioned in the previous section question the necessity of the park and whether it should be built. Beyond the engagement process that they do not perceive to be inclusive, they see the park as an intentional effort to bring development and gentrification to the area east of the river, in a way that supports the District's goals of economic development but overlooks the marginalized and the poor. One of them specifically said that the project fits within the District's goal of displacing Black residents in a city that was once dominated by their presence.

From a different angle, some simply don't see the bridge as a priority for D.C. For example, one of the interviewees, a government official in the District's Department of Energy and Environment, questioned the need for more green space in this area, considering that the adjacent Anacostia National Park is one of the biggest open spaces in the District. Despite its currently underinvested state, one could argue that investing in the improvement of the Anacostia Park would be more in line with the community needs compared to a new, expensive and flashy project. The director of Bridge Park, in contrast, suggests that residents of Ward 8 are deserving of a state-of-the-art environment, and attempts to counter gentrification should be achieved by policy means, such as the EDP:

How do you say to the residents of Anacostia that they don't deserve the exact same quality as the residents of Georgetown? That's focusing on the wrong thing. What we need to do is focusing on these larger housing strategies, workforce development strategies, and small business enterprise strategies that you can get ahead of this and ensure this park and other amenities and other investments can benefit the local residents 
... If this works for a tourist from Chicago but not the local resident, then we haven't done a good job of building this EDP (Interview, Sep 2016).

In light of the history of notorious 'top down' urban renewal projects along the Anacostia in the 1950s and 1960s, Bridge Park partners claim that they value local agency and capacity, and in doing so they try to set the project apart from that legacy. Still, as mentioned earlier, the contestation around Bridge Park stems not only from the design of the park but from questioning its necessity altogether.

\section{"More than a park": Discussion}

Recent literature on just planning has highlighted the need to pay more attention to the 'translation' of theoretical concepts of justice into planning practice (Campbell \& Marshall, 2006; S. S. Fainstein, 2010; Yiftachel \& Mandelbaum, 2017). Even if the designers of the EDP did not consult political-philosophy and planning theories in its making, the Bridge Park case allows us to examine the interpretation of justice and equity concepts in concrete planning policies. Interviews with Bridge Park staff and other representatives of its partnering organizations revealed that they strongly believe in the benefits that are expected to accrue from the project to nearby communities. And yet, several limitations arise with regards to equitable planning and social justice, related to both procedural and substantive aspects. In what ways does the Bridge Park offer a path for truly equitable planning, beyond discourse, and what lessons can be drawn from this case about socially-just planning more broadly? The following section will address these questions. 
The first aspect of social justice reviewed in this paper concerned issues of representation, engagement, and inclusivity. Despite a public engagement process that extends beyond the lower rungs on Arnstein's (1969) ladder of citizen participation, towards partnership, concerns have been raised about potential co-optation of marginalized voices and publics that are not part of the engagement process (see also Arena, 2012; Uitermark \& Nicholls, 2017). Bridge Park founders claim for consent from the community, prior to initiating the project. However, it seems that the diverse communities east of the river were insufficiently represented and the process may not have been as participatory as it is being portrayed. Such tensions are emblematic of many engagement processes across the globe and show that even good intentions may result in feelings of exclusion (S. S. Fainstein, 2010).

The fact that efforts to promote Bridge Park are led mostly by NGOs, and to a lesser extent by the city, also raises questions on justice and equity with regards to public representation. Based in the framework of a well-established local organization, Bridge Park is less likely to be perceived as a top-down project, and is able to utilize existing community mobilization channels. The fact that the project is run by a nonprofit organization is possibly one explanation for the initiation of the EDP. At the same time, if Bridge Park fills a vacuum for the District, then it casts doubts on the ability and willingness of the government to promote its own equitable planning. Moreover, being an NGO does not omit Bridge Park from promoting its own interests, which may or may not align with the interest of communities east of the river (see also Arena, 2012). Having an NGO in charge of the project is not inherently negative, but it does raise questions about accountability and commitment to the public at large.

In her Just City formulation, Fainstein (2010) emphasizes that public participation should not be valorized as an end but rather serve as a useful means to arrive at just outcomes. In this 
view, broad participation and deliberation in decision-making processes, as well as the representation of various groups in the city, including marginalized ones, are important, but participation does not guarantee equity. Bridge Park follows this logic by considering both procedural and substantive aspects of development. However, my analysis shows that planning outcomes may be considered at two different scales, or thought of from two different perspectives. As some of the interviewees have argued, the EDP may provide strategies to mitigate the unjust outcomes of building the bridge, however; the very construction of the Bridge Park would be unjust with its anticipated impact on the area. To some extent, the EDP diverts the discussion away from the issue of building the park in the first place, to issues of representation and the efficacy of the proposed strategies.

This last point is a critical one: in what ways can mitigating unjust outcomes be considered just planning? Or, in other words, does Bridge Park essentially promote 'just enough' planning? Fainstein argues that even under current conditions of capitalism and neoliberal governance, planners should still try to promote just planning to the extent possible. Bridge Park's position is that the project promotes equity since not only the EDP would mitigate negative outcomes of development, but it would also provide ample opportunities for economic growth and social interaction. However, opponents of the park claim that not building the park is more just since first, the negative implications would perhaps be mitigated but still significant and second, that the park is not a priority for the area.

The Bridge Park case powerfully demonstrates how questions of justice are contested (Campbell, 2006). One could argue that the project embodies the three pillars of the Just City since it provides an equitable development plan (hence, advances equity); adopts a deliberative engagement process in which citizens are not only informed but are empowered with decision- 
making powers (democracy), and encourages a multi-ethnic, multi-cultural and multi-racial environment due to its vision of connecting communities (diversity). However, each of these components could be contested by arguing that not everyone has been included in the decisionmaking process; that the EDP is insufficient in scope; and that issues of race are not fully engaged with. East of the river communities are in need of better education, transportation and healthcare services, and more employment opportunities. The EDP addresses some of these needs, but at a cost. Moreover, east of the river communities deserve improvements regardless of a flagship project. While the Bridge Park might be 'just' at the project's scale and from the perspective of its leaders, the NGOization of justice in this case is problematic. Bridge Park is a nonprofit, and as such, cannot be held entirely accountable for development east of the river. The local government is a stakeholder in the advancement of the bridge, but its relatively marginal role suggests a shift in the responsibilities for equitable development. As well, the funding for the park relies almost exclusively on private sector financing, which too affects the nature of the project.

Beyond issues of representation, aspects of cultural diversity and recognition-diversity being suggested by Fainstein (2010) as one of the pillars of the Just City_are somewhat sidelined in the Bridge Park, particularly racial ones. Given that the future park is situated in an area of D.C. that has been influenced, like most of the District (and other cities in the US, see Song, 2015), by unequal racial relations, it is perhaps surprising that the discourse of the park and the EDP mostly shies away from aspects of racial justice. The project is not entirely colorblind; for example, a Lantern Walk held in September 2016 recognized the heritage of the African-American builders of Historic Anacostia. However, the discourse of the EDP is generally neutral (with only one brief mention of race on p.4), giving the impression that the 
differences between the two sides of the river are mostly class-based. Racial issues also manifest in who has the available time and means to take part in the participation process and express their voice since race, economic status and marginality are clearly intertwined (Song, 2015). Indeed, Yiftachel et al. (2009) have shown that recognition is insufficient in and of itself to promote justice, since it can take a hostile form. Yet sidelining aspects of identity, race and ethnicity is not likely to lead to just planning either (Bollens, 2000). Again, Bridge Park promoters are well-aware of past racial injustices, and some efforts are made in this respect. At the same time, they do not fully address the meaning and implication of the project on racial inequalities in D.C.

\section{Conclusion}

Bridge Park leaders claim that it presents a new model for equitable development, built in collaboration with the community and for them, and backed by workable tools such as the EDP. In this respect, the Bridge Park brings us a step closer in the path towards bridging theoretical conversations about justice with planning practice (Campbell \& Marshall, 2006). Nonetheless, my analysis suggests that despite the rhetoric of equity, the Bridge Park still reproduces significant injustices. It shows that even extensive public engagement processes are not necessarily representative of the public at large nor just.

To be sure, any development can be perceived as controversial, especially in areas that are prone to gentrification and displacement. In order to create a truly just planning process, led by an equity-first approach, Bridge Park must extend its current recruitment efforts and pay special attention to the community's most vulnerable members. Such an inclusive process, however, might deliver the outcome that Bridge Park is not a priority for the area, and 
alternatives may be presented instead. In order to produce fair planning outcomes, the alleged benefits from the park must be substantial, comprehensive, and affect not only the well-off segments of the community but also those who are most at risk from being priced out from the area.

One must be careful in dismissing the intent behind Bridge Park altogether, since projects that go beyond symbolic inclusion of social justice goals in their vision statements are still few, and even fewer translate goals into actionable policies. Nonetheless, the project needs to be evaluated not only based on its discursive goals but in terms of its actual success to bridge equity. It is too soon to evaluate whether and how Bridge Park will achieve its goals and how it will affect its nearby environment, yet preliminary lessons about justice, equity and planning can already be drawn.

\section{References}

Anderson, L. M., \& Cordell, H. K. (1988). Influence of trees on residential property values in Athens, Georgia (USA): A survey based on actual sales prices. Landscape and Urban Planning, 15(1-2), 153-164.

Arena, J. (2012). Driven from New Orleans: How nonprofits betray public housing and promote privatization. Minneapolis: University of Minnesota Press.

Arnstein, S. R. (1969). A ladder of citizen participation. Journal of the American Institute of Planners, 35(4), 216-224.

Avni, N. (2017). Planning a Just City: Examining waterfront redevelopment projects from a social justice perspective. School of Urban Planning, McGill University.

Avni, N., \& Yiftachel, O. (2014). The New Divided CIty? Planning and "gray space" between 
global north-west and south-east. In S. Parnell \& S. Oldfield (Eds.), A Routledge Handbook on Cities of the Global South (pp. 487-505). London: Routledge.

Bogle, M., Diby, S., Burnstein, E., Woluchem, M., \& Dev, J. (2016). Equitable Development Planning and Urban Park Space: Early Insights from DC's 11th Street Bridge Park Project. Urban Institute.

Bollens, S. A. (2000). On narrow ground: Urban policy and ethnic conflict in Jerusalem and Belfast. Albany, N.Y: State University of New York Press.

Bratt, R., \& Reardon, K. (2013). Beyond the ladder: new ideas about resident roles in contemporary community development. In N. Carmon \& S. Fainstein (Eds.), Policy, planning, and people: Promoting justice in urban development (pp. 356-381). Philadelphia: University of Pennsylvania Press.

Building Bridges Across the River. (2015). 11th Stret Bridge Park: Equitable Development Plan. Retrieved from https://bridgepark.org/sites/default/files/Resources/EDP Final UPDATED.pdf

Campbell, H. (2006). Just Planning: The Art of Situated Ethical Judgment. Journal of Planning Education and Research, 26(1), 92-106.

Campbell, H., \& Marshall, R. (2006). Towards justice in planning: A reappraisal. European Planning Studies, 14(2), 239-252.

Campbell, H., Tait, M., \& Watkins, C. (2014). Is there space for better planning in a neoliberal world? Implications for planning practice and theory. Journal of Planning Education and Research, 34(1), 45-59.

Cardoso, R., \& Breda-Vazquez, I. (2007). Social justice as a guide to planning theory and practice: analyzing the Portuguese planning system. International Journal of Urban and 
Regional Research, 31(2), 384-400.

Carmon, N., \& Fainstein, S. (2013). Policy, Planning, and People: Promoting Justice in Urban Development. Philadelphia: University of Pennsylvania Press.

Connolly, J., \& Steil, J. (2009). Introduction: Finding justice in the city. In P. Marcuse, J.

Connolly, J. Novy, I. Olivo, C. Potter, \& J. Steil (Eds.), Searching for the just city: Debates in urban theory and practice (pp. 1-16). London; New York: Routledge.

Curran, W., \& Hamilton, T. (2012). Just green enough: contesting environmental gentrification in Greenpoint, Brooklyn. Local Environment, 17(9)(9), 1027-1042.

Davidoff, P. (1965). Advocacy and pluralism in planning. Journal of the American Institute of Planners, 31(4)(4), 331-338.

Fainstein, N., \& Fainstein, S. (2013). Restoring Just Outcomes to Planning Concerns: In N. Carmon \& S. Fainstein (Eds.), Policy, Planning and People: Promoting Justice in Urban Development. Philadelphia: University of Pennsylvania Press.

Fainstein, S. S. (2000). New directions in planning theory. Urban Affairs Review, 35(4)(4), 451478.

Fainstein, S. S. (2005a). Cities and diversity should we want it? Can we plan for it? Urban Affairs Review, 4l(1), 3-19.

Fainstein, S. S. (2005b). Planning theory and the city. Journal of Planning Education and Research, 25(2), 121-130.

Fainstein, S. S. (2010). The just city. Ithaca: Cornell University Press.

Fincher, R., \& Iveson, K. (2012). Justice and Injustice in the City. Geographical Research, 50(3)(3), 231-241.

Fischer, F. (2009). Discursive planning: Social justice as discourse. In P. Marcuse, J. Connolly, 
J. Novy, C. Potter, \& J. Steil (Eds.), Searching for the just city: Debates in urban theory and practice (pp. 52-71). London; New York: Routledge.

Forester, J. (1999). The deliberative practitioner: Encouraging participatory planning processes. Cambridge, Mas: MIT Press.

Fraser, N. (1998). Social justice in the age of identity politics: Redistribution, recognition, and participation. In Working paper (pp. 98-108). Berlin: SSG Sozialwissenschaften, USB Köln.

Fraser, N., \& Honneth, A. (2003). Redistribution or recognition?: a political-philosophical exchange. London New York: Verso.

Graber, H. (2014). Can This Man Bridge Two Disparate D.C. Communities—and a River? CityLab, https://www.citylab.com/design/2014/10/can-this-ma. Retrieved from https://www.citylab.com/design/2014/10/can-this-man-bridge-two-disparate-dccommunitiesand-a-river/381555/

Harvey, D. (1973). Social justice and the city (Vol. 1). Baltimore: Johns Hopkins University Press.

Harvey, D., \& Potter, C. (2009). The right to the just city. In P. Marcuse (Ed.), Searching for the just city: debates in urban theory and practice (pp. 40-51). London; New York: Routledge.

Healey, P. (2003). Collaborative planning in perspective. Planning Theory, 2(2), 101-123.

Heckert, M., \& Mennis, J. (2012). The economic impact of greening urban vacant land: A spatial difference-in-differences analysis. Environment and Planning A, 44(12), 3010-3027. https://doi.org/10.1068/a4595

Heynen, N., Aiello, D., Keegan, C., \& Luke, N. (2018, March 4). The Enduring Struggle for Social Justice and the City. Annals of the American Association of Geographers, 108(2), 
301-316.

Huxley, M., \& Yiftachel, O. (2000). New paradigm or old myopia? Unsettling the communicative turn in planning theory. Journal of Planning Education and Research, 19(4), 333-342.

Innes, J. E. (1995). Planning theory's emerging paradigm: communicative action and interactive practice. Journal of Planning Education and Research, 14(3), 183-189.

Kennicott, P. (2014). Further details about 11th Street Bridge Park show why ' $X$ ' marked the sweet spot. Retrieved from https://www.washingtonpost.com/entertainment/museums/further-details-about-11th-streetbridge-park-show-why-X-marked-the-sweet-spot/2014/10/16/7407d088-5568-11e4-809b8cc0a295c773_story.html?utm_term=.3b006d396bd9

Kent, A., \& Kratz, S. (2017). Physically, Economically, and Socially Bridging Washington, D.C. Retrieved January 16, 2017, from https://revitalizationnews.com/article/guest-articlephysically-economically-socially-bridging-washington-dc/

Kolson Hurley, A. (2016). Bridging D.C.'s Starkest Divide: Can a park over the Anacostia River spur a revolution in urban development? Retrieved November 21, 2016, from https://nextcity.org/features/view/washington-dc-anacostia-11th-street-bridge-park-plans

Lake, R. (2017). Justice as subject and object of planning. International Journal of Urban and Regional Research, 40(6), 1205-1220.

Larson, S. M. (2018). Imagining social justice and the false promise of urban park design. Environment and Planning A, 50(2), 391-406.

Marcuse, P. (2009). Spatial justice: derivative but causal of social injustice. Justice Spatiale/Spatial Justice, 1, 1-6. 
Marcuse, P., Connolly, J., Novy, J., Olivo, I., Potter, C., \& Steil, J. (2009). Searching for the just city: debates in urban theory and practice. London; New York: Routledge.

Merrifield, A., \& Swyngedouw, E. (1996). The urbanization of injustice. New York: New York University Press.

Novy, J., \& Mayer, M. (2009). As" just"'” as it gets? The European city in the" Just City" discourse. In P. Marcuse, J. Connolly, J. Novy, I. Olivo, \& J. Steil (Eds.), Searching for the just city: Debates in urban theory and practice (pp. 103-119). London; New York: Routledge.

O'Connell, J. (2017). Big philanthropists flock to D.C.'s Bridge Park project to battle gentrification. The Washington Post. Retrieved from https://www.washingtonpost.com/news/digger/wp/2017/09/25/big-philanthropists-flock-tod-c-s-bridge-park-project-to-battle-gentrification/?utm_term=.b56bfed10fbf

Parnell, S., \& Oldfield, S. (2014). The Routledge Handbook on Cities of the Global South. Routledge. New York; London: Routledge.

Pearsall, H. (2018). The Contested Future of Philadelphia's Reading Viaduct: Blight, Neighborhood Amenity, or Global Attraction? In T. Curran, Winifred; Hamilton (Ed.), Just Green Enough (pp. 197-208). Routledge in association with GSE Research.

Porter, L., \& Yiftachel, O. (2017). Urbanizing settler-colonial studies: introduction to the special issue. Settler Colonial Studies, 1-10.

Roy, A. (2009). Strangely Familiar: Planning and the Worlds of Insurgence and Informality. Planning Theory, 8(1), 7.

Sandercock, L. (1998). Towards cosmopolis: Planning for multicultural cities. England: Wiley Chichester. 
Soja, E. W. (2010). Seeking spatial justice. Minneapolis: University of Minnesota Press.

Song, L. K. (2015). Race, transformative planning, and the just city. Planning Theory, 14(2), 152-173.

Steinhauer, J. (2014). Building a Park to Span a Divide in Washington. The New York Times. Retrieved from https://www.nytimes.com/2014/12/29/us/building-a-park-to-span-a-dividein-washington-anacostia-river.html

Uitermark, J., \& Nicholls, W. (2017). Planning for social justice: Strategies, dilemmas, tradeoffs. Planning Theory, 16(1), 32-50.

Watson, V. (2013). Planning and the 'stubborn realities' of global south-east cities: Some emerging ideas. Planning Theory, 12(1), 81-100.

Wennersten, J. R. (2008). Anacostia: The Death \& Life of an American River. Baltimore, MD: The Chesapeake Book Company.

Williams, M. (2016). Searching for actually existing justice in the city. Urban Studies, 1-15.

Yiftachel, O. (2006). Re-engaging Planning Theory? Towards 'South-Eastern. Planning Theory, $5,211-222$.

Yiftachel, O., Goldhaber, R., \& Nuriel, R. (2009). Urban justice and recognition: affirmation and hostility in Beer Sheva. In P. Marcuse, J. Connolly, I. Olivo, C. Potter, \& J. Steil (Eds.), Searching for the just city: debates in urban theory and practice (Vol. 1, pp. 120-143). London; New York: Routledge.

Yiftachel, O., \& Mandelbaum, R. (2017). Doing the Just City: Social Impact Assessment and the Planning of Beersheba, Israel. Planning Theory \& Practice, 18(4), 525-548.

Young, I. M. (1990). Justice and the Politics of Difference. Princeton, N.J.: Princeton University Press. 


\section{Captions:}

Table 1: Snapshot of the Bridge Park Impact Area.

Source: Based on the 11th Street Bridge Park Equitable Development Plan, p.7

Table 2: Summary of the Equitable Development Plan

Figure 1: A) The location of the $11^{\text {th }}$ Street Bridge Park Bridge in relation to the District of Columbia. Source: Wikimedia Commons

B) The area surrounding the $11^{\text {th }}$ Street Bridge Park.

Source: Google Maps

\footnotetext{
i The West area census track includes a large Hope VI project, which increases the percentage of renter occupied units, and potentially the unemployment and child poverty rates.

ii Precise figures vary according to different press releases; moreover, incoming donations change the status on a continuous basis.
} 